\title{
Isolation of different types of birnavirus from ayu Plecoglossus altivelis and amago salmon Oncorhynchus rhodurus cultured in the same geographic area
}

\author{
Sung-Ju Jung*, Shin-Ichi Kitamura, Kenji Kawai, Satoru Suzuki** \\ Department of Aquaculture, Kochi University, Nankoku, Kochi 783-8502, Japan
}

\begin{abstract}
A birnavirus was recently isolated from cultured ayu Plecoglossus altivelis on Shikoku island, Japan. The diseased fish displayed vertebral or vertical curvature and mild haemorrhage around the brain. Cytopathic effects (CPE) of the virus, including cell roundness, filamentous change and cell lysis, were observed in CHSE-214, RTG-2 and RSBK-2 cells. The virus isolated from ayu, designated the AY-98 strain, was found to be antigenically related to the marine birnavirus (MABV) Y-6 strain that originated from yellowtail Seriola quinqueradiata. AY-98 had a bi-segmented RNA genome and the same nucleotide sequence in the $310 \mathrm{bp} \mathrm{VP2/NS} \mathrm{junction} \mathrm{as} \mathrm{MABV} \mathrm{Y-} 6$. At the same time that the ayu epizootics occurred, another birnavirus (AM-98) was isolated from amago salmon Oncorhynchus rhodurus which were cultured $66 \mathrm{~km}$ away from the ayu farm. AM-98 showed a similar $\mathrm{CPE}$ and had the same host cell ranges as AY-98. However, AM-98 was serologically similar to the VR299 strain of infectious pancreatic necrosis virus (IPNV) and their nucleotide sequences in the VP2/ NS junction region showed $98 \%$ homology without changes at the amino acid level. In this study, the ayu strain AY-98 was grouped into MABV, whereas the amago salmon strain AM-98 was grouped into IPNV. This indicates that the 2 birnaviruses originated from different sources in spite of the fact that the places where they were isolated are close to one another. The results in this paper show a new aspect of the traditional consensus that the same serogroup of birnavirus distribute in close geographic areas.
\end{abstract}

KEY WORDS: Ayu $\cdot$ MABV $\cdot$ Amago salmon · IPNV · Geographic area

\section{INTRODUCTION}

The family Birnaviridae has a bisegmented doublestranded RNA genome within an unenveloped capsid (Dobos et al. 1979, Brown 1986). Aquatic birnaviruses are included in this family, and are widely distributed. Infectious pancreatic necrosis virus (IPNV) is the most well-known virus among aquatic birnaviruses, and is an important pathogen in several species of salmonids (Wolf 1988). In the last decade, IPNV-like birnaviruses have also been implicated in diseases in many marine fish such as yellowtail Seriola quinqueradiata, Japan-

\footnotetext{
- Present address: Department of Fish Pathology, Yosu University, Yosu 550-743, Korea.

•-Corresponding author. E-mail: ssuzuki@cc.kochi-u.ac.jp
}

ese flounder Paralichthys olivaceus and red sea bream Pagrus major (Sorimachi \& Hara 1985, Kusuda et al. 1989, 1993). Although all the isolates of aquatic birnaviruses including IPNV and marine origin viruses are antigenically related, 3 major serotypes, $\mathrm{Ab}, \mathrm{Sp}$ and VR-299, are known in IPNV (Okamoto et al. 1983, Wolf 1988, Kusuda et al. 1993). Geographically, the Ab and Sp serotypes were considered to be mainly distributed in Europe, whereas the VR-299 was considered to be a North American serotype (Wolf 1988). In Asia, isolates related to $\mathrm{Ab}, \mathrm{Sp}$ and VR-299 serotypes have been reported (Hedrick et al. 1985, Chou et al. 1993, Hsu et al. 1993, Sohn et al. 1995). Recently, Kusuda et al. (1993) compared the serological characteristics among several marine birnaviruses (MABV) strains and concluded that MABV should be grouped in a new serogroup of IPNV. Hosono et al. (1996) performed 
genogrouping based on amino acid sequences in the variable VP2/NS junction region and also demonstrated that $\mathrm{MABV}$ is distinguishable in genogroup from IPNV.

In 1998, we isolated a virus with the characteristics of a birnavirus from diseased ayu Plecoglossus altivelis obtained from a fish farm on Shikoku island, Japan. Although several bacterial, fungal and parasitic diseases of ayu have been reported (Takahashi \& Egusa 1977, Wakabayashi 1994, Nakatsugawa \& Iida 1996), viral diseases have not been reported in this species. This study is the first report of a virus infection in ayu. At the same time that the birnavirus was isolated from ayu, another birnavirus was isolated from amago salmon Oncorhynchus rhodurus in an area geographically close to an ayu farm.

In this study, we conducted virus characterization, serological and molecular biological investigations of the 2 viruses, which appear to show that the ayu strain belongs to $\mathrm{MABV}$, whereas the amago salmon strain belongs to IPNV VR-299.

\section{MATERIALS AND METHODS}

Situation and symptoms of ayu. The fish hatched in an ayu hatchery located in the centre of Kochi Prefecture, then were transported to a farm in western part of the Prefecture (Fig. 1). Ayu fingerlings (1 to $2 \mathrm{~g}$, 90 to $120 \mathrm{~d}$ old) showed an epizootic from the middle of February to early March 1998. The water temperature at the time was around $19^{\circ} \mathrm{C}$. Mortality occurred in smaller fish and was approximately $1 \%$ per day. Diseased ayu displayed vertebral or vertical curvature with mild exophthalmus and haemorrhaging around the brain.

Situation and symptoms of amago salmon. The amago salmon farm was located $66 \mathrm{~km}$ from the ayu farm as shown in Fig. 1. The amago salmon were produced in a culture farm in 1998 and were 1 to $2 \mathrm{~g}$ in size when mortality occurred. The mortality rate of amago salmon was less than $1 \% \mathrm{~d}^{-1}$ and water temperature was around $14^{\circ} \mathrm{C}$. Diseased fish displayed symptoms such as a decrease in appetite with a darkened body and occasionally abnormal swimming. Mild exophthalmus and haemorrhage in the pectoral and pelvic fins were observed.

Virus isolation and cell lines. The whole body minus the caudal peduncle area of ayu and the kidney of the amago salmon was homogenated in Hanks' solution (Nissui). The homogenate was centrifuged at low speed and then the filtered supernatant was inoculated onto chinook salmon embryo (CHSE-214) cells. Other cell lines such as rainbow trout gonad (RTG-2), red sea bream kidney (RSBK-2), epithelial papilloma of carp

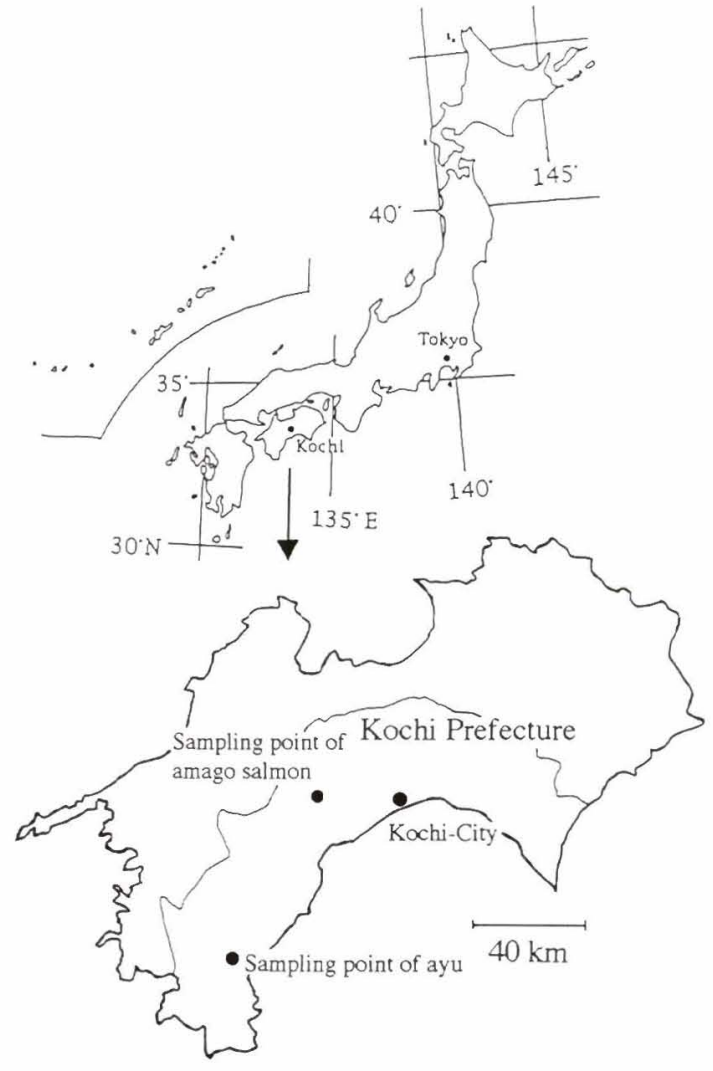

Fig. 1. Location of sampling points of ayu Plecoglossus altivelis and amago salmon Oncorhynchus rhodurus on Shikoku island, Japan

(EPC), bluegill fin (BF-2) and fathead minnow fin (FHM) were used for a cell susceptibility assay.

Neutralization test. MABV strain Y-6 (Kusuda et al. 1993) and IPNV strains Ab, Sp and VR-299 were used as reference strains. The antigenic relatedness of the 2 isolates to the reference strains was analyzed with antisera against the references using the method of Okamoto et al. (1983). Viruses (100 $\left.\mathrm{TCID}_{50} / 50 \mu \mathrm{l}\right)$ were mixed with serial 2-fold dilutions of antiserum and were incubated at $20^{\circ} \mathrm{C}$ for $60 \mathrm{~min}$. The $100 \mu \mathrm{l}$ of the mixtures were inoculated into CHSE-214 cells and incubated at $20^{\circ} \mathrm{C}$ for $10 \mathrm{~d}$. The $50 \%$ neutralizing titer was calculated according to the method of BehrensKarber.

Virion RNA analysis. Virion was purified from cultured supernatant. Cellular debris was removed by centrifugation at $2000 \times \mathrm{g}$ for $20 \mathrm{~min}$, and then $6.5 \%$ polyethylene glycol 20000 (Wako) and $2.3 \% \mathrm{NaCl}$ was added to the supernatant. The supernatant was overlaid on the layers of $40 \% \mathrm{CsCl}$ and $30 \%$ sucrose in TNE buffer (0.01 M Tris, $0.1 \mathrm{M} \mathrm{NaCl}, 0.001 \mathrm{M}$ EDTA, $\mathrm{pH} 7.5)$ followed by centrifugation at $100000 \times \mathrm{g}$ for $90 \mathrm{~min}$. Virion was banded between the 2 layers. Proteinase $\mathrm{K}$ (TaKaRa) was added to the collected virion 
fraction, to a final concentration of $100 \mu \mathrm{g} \mathrm{ml}^{-1}$, and the mixture was incubated at $42^{\circ} \mathrm{C}$ for $1 \mathrm{~h}$. The solution was extracted with phenol and chloroform and the RNA in the aqueous phase was recovered by ethanol precipitation. RNA was analyzed by SDS-polyacrylamide gel electrophoresis (PAGE) (Laemmli 1970) using a $10 \%$ polyacrylamide gel run at $5 \mathrm{~mA}$ for $20 \mathrm{~h}$. The RNA segments were stained with a silver stain kit (Daiichi).

Reverse transcription - polymerase chain reaction (RT-PCR) and sequencing. RT-PCR and the sequence analysis were performed as described by Suzuki et al. (1997a, 1998a). Briefly, 310 bp PCR product from the VP2/NS junction region of the genome segment $A$ was obtained by PCR with primer set of P1: 5'-AGAGATCACTGACTTCACAAGTGAC-3' and P2: 5'-TGTGCACCACAGGAAAGATGACTC-3' (Suzuki et al. 1997a). Amplified fragments were used for direct sequencing using a DNA sequencer 373A (ABI) and an ABI PRISMTM Dye Terminator Cycle Sequencing Kit (Perkin Elmer). Sequence analysis was performed by Genetyx-Mac version 8.0.

\section{RESULTS}

\section{Virus isolation}

Viruses isolated from ayu and amago salmon showed typical cytopathic effect (CPE) in CHSE-214, RTG-2 and RSBK-2. Infected cells became round and filamentous in the early stage of infection. Most of the cells were detached from the bottom of the flask within 3 to $4 \mathrm{~d}$. The viruses isolated from ayu and amago salmon were designated AY-98 and AM-98, respectively. Both isolates induced only a very weak CPE in FHM and BF-2 cells.

\section{Virus neutralization}

The antigenic relationship among AY-98, AM-98 and 4 reference strains is shown in Table 1. AY-98 was serologically similar to MABV Y-6, whereas AM-98 was similar to IPNV VR-299. Both isolates were antigenically distinguished from IPNV Ab and Sp.

\section{Virion RNA analysis}

The RNA of AY-98 and AM-98 each consisted of 2 segments (Fig. 2). The sizes of the segments in AY-98 were identical to those of MABV Y-6, whereas the sizes of the segments in AM-98 were identical to those of IPNV VR-299.
Table 1. Serological relationship of the ayu isolate (AY-98) and amago salmon isolate (AM-98) with the reference serotypes

\begin{tabular}{|c|c|c|c|c|}
\hline \multirow[t]{2}{*}{ Birnavirus } & \multicolumn{4}{|c|}{ Anti-sera } \\
\hline & $\mathrm{Ab}$ & $\mathrm{Sp}$ & VR-299 & MABV Y-6 \\
\hline IPNV $\mathrm{Ab}$ & $4787^{\mathrm{a}}$ & 166 & 1136 & 1328 \\
\hline IPNV Sp & 568 & 37902 & 2272 & 1327 \\
\hline IPNV VR-299 & 350 & 332 & 10809 & 315 \\
\hline MABV Y-6 & 48 & 178 & 1136 & 5311 \\
\hline AY-98 & 82 & 256 & 663 & 21247 \\
\hline AM-98 & 71 & 284 & 4548 & 1136 \\
\hline
\end{tabular}
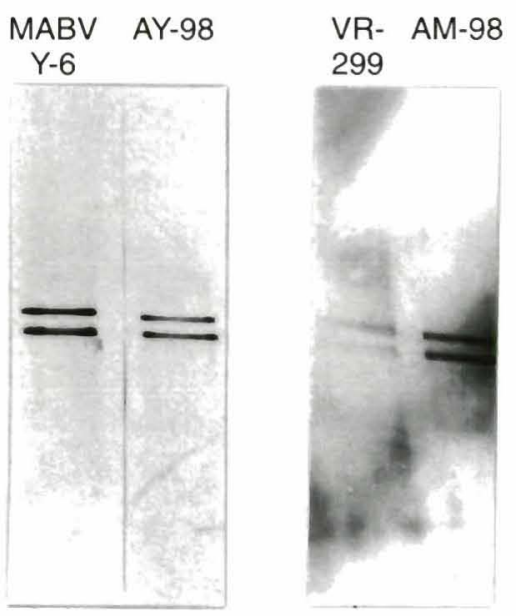

Fig. 2. RNA electrophoretic pattern of the isolates with reference strains (MABV Y-6 and IPNV VR-299)

\section{RT-PCR and sequencing}

Fig. 3 shows nucleotide sequences of the PCR products of AY-98 and AM-98, and their corresponding portion of MABV Y-6 and IPNV VR-299. AY-98 was $100 \%$ homologous to MABV Y-6. On the other hand, AM-98 exhibited $98 \%$ homology with IPNV VR-299. In the deduced amino acid sequence, AM-98 showed 100\% homology with IPNV VR-299.

\section{DISCUSSION}

From the results of the neutralization tests and virion RNA analyses, the 2 isolates from ayu and amago salmon were found to belong to the birnaviridae. This is the first report of a viral infection in ayu. The isolate from ayu, AY-98, exhibited similarities to MABV. MABV has been reported only in marine fish (Sorimachi \& Hara 1985, Kusuda et al. 1993) and shellfish species (Suzuki et al. 1997a, 1998b). Hosono et al. (1996) reported that MABV is in a genogroup that is 


\begin{tabular}{|c|c|c|c|c|c|c|c|c|c|c|c|c|}
\hline AY98 & & $\mathrm{CTCCC}$ & AACCT & CAAAA & GCCTG & GGGGT & GGAGA & GACAT & TGTGA & GAGGC & ATCCG & \\
\hline MABV & $Y-6$ & $\ldots$ & $\ldots$ & $\ldots$ & $\ldots \ldots$ & $\ldots$ & $\ldots$ & $\ldots$ & $\ldots$ & $\ldots \ldots$ & $\ldots$ & \\
\hline AM98 & & CTACC & $\mathrm{AACCT}$ & CAAAG & GCATG & GGGAT & GGAGG & GACCT & GGTCA & GAGGC & ATCAG & \\
\hline IPNV & VR299 & $\star \star \star \star \star \star ~$ & 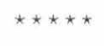 & 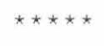 & $\star \star \star \star \star \star ~$ & 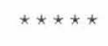 & 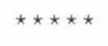 & 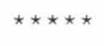 & $\star \star \star \star \star \star ~$ & 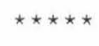 & 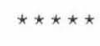 & \\
\hline & & GAAGG & TGGCA & GCACC & AGTGC & TGTCA & $\mathrm{ACACT}$ & CTTCC & CCATG & GCGGC & ACCAC & \\
\hline$A B V$ & $Y-6$ & $\ldots$ & $\cdots$ & $\cdots$ & $\ldots \ldots$ & $\cdots$ & $\ldots$ & $\cdots$ & $\ldots$ & $\ldots$ & $\ldots$ & \\
\hline & & AAAAG & TGGCC & $\mathrm{GCCCC}$ & CGTGC & TGTCA & ACGCT & CTTCC & CAATG & GCGGC & TCCCC & \\
\hline & VR299 & $\star \star \star \star \star \star$ & 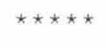 & $\star \star \star \star \star \star$ & $\star \star \star \star \star$ & 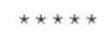 & $\star \star \star \star \star \star$ & $\star \star \star \star \star \star ~$ & 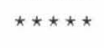 & 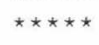 & $\star \star \star \star \star$ & \\
\hline 69 & & TCATC & GGAGC & CGCCG & $A C C A A$ & TTCAT & CGGAG & ACCTG & ACCAA & GACCA & ACGCA & \\
\hline & $Y-6$ & $\ldots$ & $\ldots$ & $\ldots$ & $\ldots$ & $\ldots$ & $\ldots$ & $\ldots$ & $\ldots$ & $\ldots$ & $\ldots$ & \\
\hline 0 & & TCATA & GGGGC & GGCCG & ACCAA & TTCAT & TGGGG & $\mathrm{ACCTC}$ & ACCAA & GACCA & ACTCA & \\
\hline & VR299 & $\star T^{\star} \star \star$ & $\star \star A \star \star$ & $\mathrm{T} \star \star \star \star$ & $\star \star \star \star \star$ & $\star \star \star \star \star \star$ & $\star \star \star \star \star$ & $\star \star \star \star \star \star$ & $\star \star \star \star \star \star$ & $\star \star \star \star \star$ & $\star \star \star \star \star$ & \\
\hline & & GCCGG & AGGCC & GCTAC & CTAAC & ACATG & CAGCA & GGAGG & ACGCT & $\mathrm{ACACT}$ & GACGT & \\
\hline & $Y-6$ & $\ldots$ & $\ldots$ & $\ldots$ & $\ldots$ & $\ldots$ & $\ldots$ & $\ldots$ & $\ldots$ & $\ldots$ & $\ldots$ & \\
\hline & & GCCGG & GGGAC & GCTAC & CAGTC & ACACG & CAGCC & GGAGG & $\mathrm{CCGCT}$ & ACCAT & GATGT & \\
\hline & VR299 & 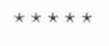 & $\star \star \star \star \star \star$ & $\star \star \star \star \star ~$ & $\star \mathrm{T} \star \star \star$ & $\star \star \star \star \star \star$ & $\star \star \star \star \star \star$ & $\star \star \star \star \star$ & $\star \star \star \star \star ~$ & $\star \star \star \star \star$ & $\star \star \star \star \star$ & \\
\hline & & AATGG & ACTCC & TGGGC & CAGCG & GCACA & GACAC & TGGGA & GGTTC & TCACG & CAACC & \\
\hline$A B V$ & $Y-6$ & $\ldots$ & $\ldots$ & $\ldots$ & $\ldots$ & $\ldots$ & $\ldots$ & $\ldots$ & $\ldots$ & $\ldots$ & $\ldots$ & \\
\hline & & CATGG & ACTCA & TGGGC & CAGCG & GGTCC & GAGGC & AGGAA & GCTAC & TCAAA & GCACC & \\
\hline & VR299 & 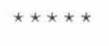 & $\star \star \star \star \star \star$ & $\star \star \star \star \star \star$ & $\star \star \star \star \star$ & $\star \star \star \star \star \star$ & $\star \star \star \star \star \star$ & $\star \star \star \star \star$ & $\star \star \star \star T \mathrm{~T}$ & $\star \star \star \star \star \star$ & $\star \star \star \star \star$ & \\
\hline & & TCAAA & GACCG & GCTGG & AGTCA & AACAA & CTATG & AGGAG & ATGGA & ACTTC & CTCCA & \\
\hline & $Y-6$ & $\ldots$ & $\ldots \ldots$ & $\ldots$ & $\ldots$ & $\ldots$ & $\ldots \ldots$ & $\ldots$ & $\ldots \ldots$ & $\ldots \ldots$ & $\ldots$ & \\
\hline$A M$ & & TCAAG & $\mathrm{ACCCG}$ & GCTTG & AGTCC & AACAA & CTATG & AGGAA & GTGGA & GCTTC & CAAAG & 0 \\
\hline & VR299 & $\star \star \star \star \star ~$ & $\star \star \star \star \star$ & 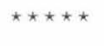 & $\star \star \star \star \star \star$ & $\star \star T * \star$ & $\star \star \star \star \star \star$ & $\star \star \star \star \star \star$ & 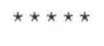 & $\star \star \star \star \star$ & $\star \star \star \star \star \star$ & \\
\hline & & CCAAC & GAAAG & & & & & & & & & \\
\hline & $Y-6$ & $\ldots$ & $\ldots$ & & & & & & & & & \\
\hline & & CCAAC & AAAGG & & & & & & & & & \\
\hline & R29 & $\star \star \star \star \star \star$ & & & & & & & & & & \\
\hline
\end{tabular}

Fig. 3. Comparison of nucleotide sequences of the VP2/NS junction region in the isolates (AY-98 and AM-98) and reference strains (MABV Y-6 and IPNV VR-299) different from known IPNV strains in terms of the amino acid sequence in the VP2/NS junction region. The nucleotide sequence of AY-98 had 100\% homology with MABV, suggesting that AY-98 is of marine origin. At almost the same time, another birnavirus, AM-98, was isolated from amago salmon from a nearby area. Characteristics of this isolate were very similar to those of IPNV VR-299, indicating the 2 isolates have independent origins.

The infection route of MABV to ayu may be through sea water, because 10 to $100 \%$ sea water is used for 2 or 3 mo for rearing fry and fingerling in most ayu hatcheries. In addition, in our survey of birnaviruses, the MABV genome was detected by PCR from concentrated sea water collected from the coast area close to the ayu hatchery, supporting the possibility of MABV infection via sea water. Since the brood stock has been cultured in a well-controlled fresh water system for several years in the hatchery, we hypothesize that the route of infection of MABV to ayu was via sea water rather than via fresh water. However, the possibility of vertical transmission cannot be neglected, because IPNV carrier fish can vertically transmit the virus to progeny (Billi \& Wolf 1969, Ahne \& Negele 1985, Dor- son \& Torchy 1985). Ayu are anadromous fish which spend their fry to fingerling period in the sea. A survey of MABV in natural populations of ayu in the sea and river is needed to clarify the infection route of MABV and distribution in the natural environment.

The general geographical distribution of IPNV strains is known. The Ab and Sp serotypes are found in Europe, whereas the VR-299 serotype is found in North America (Wolf 1988). In Asia, all serotypes have been reported in several host species (Hedrick et al. 1985, Chou et al. 1993, Hsu et al. 1993, Sohn et al. 1995). Rivas et al. (1993) reported that most isolates from trout and bivalve molluscs in the same area belong to the Sp serotype. In this study, in spite of the fact that AY-98 and AM-98 were isolated at the same time in nearby areas, they were classified into different groups of viruses. AM-98 from amago salmon was antigenically similar to IPNV VR-299 in the neutralization test, and its amino acid sequence also had 100\% homology in the VP2/NS junction region. This suggests that AM-98 may have originated in North America and introduced brood stock in mainland Japan.

In this manuscript, we suggest that the movement of fish to different geographical areas should be stopped, 
since this increases the risk of spreading pathogens and causes new diseases in new species. Further study is needed to determine detailed characteristics of AY98 and its pathogenicity. Moreover, a survey of MABV distribution in natural fresh water and farming areas needs to be considered, and the effects on host species determined.

\section{LITERATURE CITED}

Ahne W, Negele RD (1985) Studies on the transmission of infectious pancreatic necrosis virus via eyed eggs and sexual products of salmonid fish. In: Ellis AE (ed) Fish and shellfish pathology. Academic Press, London, p 261-269

Billi JL, Wolf K (1969) Quantitative comparison of peritoneal washes and feces for detecting infectious pancreatic necrosis (IPNV) virus in carrier brook trout. J Fish Res Board Can 26:1459-1465

Brown F (1986) The classification and nomenclature of viruses: summary of results of meetings of the International Committee on Taxonomy of Viruses in Sendai, September 1984. Intervirol 25:140-143

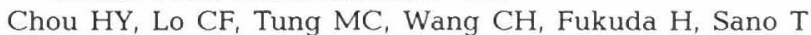
(1993) The general characteristics of a birnavirus isolated from cultured loach (Misgurnus anguillicaudatus) in Taiwan. Fish Pathol 28:1-7

Dobos P, Hill BJ, Hallet R, Kells DTC, Becht H (1979) Teninges biophysical and biochemical characterization of five animal viruses with bisegmented double-stranded RNA genomes. J Virol 32:593-605

Dorson M, Torchy C (1985) Experimental transmission of infectious pancreatic necrosis via the sexual products. In: Ellis AE (ed) Fish and shellfish pathology. Academic Press, London, p 251-260

Hedrick RP, Eaton WD, Fryer JL, Hah YC, Park JW, Hong SW (1985) Biochemical and serological properties of birnavirus isolated from fish in Korea. Fish Pathol 20:463-468

Hosono N, Suzuki S, Kusuda R (1996) Genogrouping of birnavirus isolated from marine fish: a comparison of VP2/NS junction regions on genome segment A. J Fish Dis 19: 295-302

Hsu YL, Chen BS, Wu JL (1993) Demonstration of infectious pancreatic necrosis virus strain VR-299 in Japanese eel, Anguilla japonica Temminck \& Schlegel. J Fish Dis 16: 123-129

Kusuda R, Kado K, Takeuchi Y, Kawai K (1989) Characteris-

Editorial responsibility: Jo-Ann Leong,

Corvallis, Oregon, USA tics of two virus strains isolated from young Japanese flounder Paralichthys olivaceus. Suisan Zoushoku 37: 115-120 (in Japanese with English summary)

Kusuda R, Nishi Y, Hosono N, Suzuki S (1993) Serological comparison of birnavirus isolated from several species of marine fish in south west Japan. Fish Pathol 28:91-92

Laemmli UK (1970) Cleavage of structural proteins during the assembly of the head of bacteriophage T4. Nature 227: $680-685$

Nakatsugawa T, Iida Y (1996) Pseudomonas sp. isolated from diseased ayu, Plecoglossus altivelis. Fish Pathol 31: 221-227 (in Japanese with English summary)

Okamoto N, Sano T, Hedrick RP, Fryer JL (1983) Antigenic relationship of selected strains of infectious pancreatic necrosis virus and European eel virus. J Fish Dis 6:19-25

Rivas C, Cepeda C, Dopazo CP, Novoa B, Noya M (1993) Marine enviroment as reservoir of birnaviruses from poikilothermic animals. Aquaculture 115:183-194

Sohn SG, Park MA, Do JW, Choi JY, Park JW (1995) Birnavirus isolated from cultured flounder in Korea. Fish Pathol 30:279-280

Sorimachi M, Hara T (1985) Characteristics and pathogenicity of a virus isolated from yellowtail fingerling showing ascites. Fish Pathol 19:231-238 (in Japanese with English summary)

Suzuki S, Hosono N, Kusuda R (1997a) Detection of aquatic birnavirus gene from marine fish using a combination of reverse transcription and nested PCR. J Mar Biotechnol 5: 205-209

Suzuki S, Nakata T, Kamakura M, Yoshimoto M, Furukawa Y, Yamashita Y, Kusuda R (1997b) Isolation of birnavirus from agemaki (jack knife clam) Sinonovacura constricta and survey of the virus using PCR technique. Fish Sci (Tokyo) 63:563-566

Suzuki S, Kamakura M, Kusuda R (1998a) Isolation of birnavirus from Japanese pearl oyster Pinctada fucata. Fish Sci (Tokyo) 64:342-343

Suzuki S, Kimura M, Kusuda R (1998b) The complete nucleotide sequence of the polyprotein and VP5 gene of a marine birnavirus. Fish Sci (Tokyo) 64:428-433

Takahasi S, Egusa S (1977) Studies on Glugea infection of ayu, Plecoglossus altivelis. Description of the Glugea and a proposal of a new species, Glugea plecoglossi. Fish Pathol 11:175-182 (in Japanese with English summary)

Wakabayashi H, Toyama T, Iida T (1994) A study on serotyping of Cytophaga psychrophila isolated from fishes in Japan. Fish Pathol 29:101-104

Wolf K (1988) Infectious pancreatic necrosis. In: Fish viruses and fish viral diseases. Cornell University Press, New York, p 115-157

Submitted: March 6, 1999; Accepted: August 5, 1999 Proofs received from author(s): October 1, 1999 